\title{
RESPIRATORY ACTIVITY OF ISOLATED MITOCHONDRIA FROM ORGANS AND TISSUES OF THE ANTARCTIC FISH Trematomus bernacchii, Trematomus newnesi, Lepidonotothen nudifrons, and Pagothenia hansoni
}

\author{
MALUCELLI, M.I.C. ${ }^{1}$; SUGIZAKI, M. ${ }^{2}$; SALVO, L.M. ${ }^{3}$; LUCCHIARI, P.H. ${ }^{2}$; BACILA, M. ${ }^{2}$ \\ ${ }^{1}$ Programa Antártico Brasileiro, DTI-Conselho Nacional de Pesquisas; \\ ${ }^{2}$ Pontifícia Universidade Católica do Paraná, PUCPR; \\ ${ }^{3}$ Doutoranda, Faculdade de Medicina Veterinária e Zootecnia, USP.
}

Many of the key evolutionary adaptations for life in the Antarctic Ocean involve refinements of physiological and biochemical processes. Especially prominent are mechanisms that prevent freezing and allow cells, tissues and organs to carry on their metabolic activity at subzero water temperatures. In the present research work a study has been carried out on the respiration activity, assayed at $0^{\circ} \mathrm{C}, 5^{\circ} \mathrm{C}$ and $10^{\circ} \mathrm{C}$ of pectoral fin epaxial muscle and encephalon isolated mitochondria from the Antarctic fish Trematomus bernacchii, Trematomus newnesi, Lepidonotothen nudifrons, and Pagothenia hansoni using sodium succinate as substrate. For the interval between $0^{\circ} \mathrm{C}$ and $5^{\circ} \mathrm{C}$ respiration rate of encephalon mitochondria from Pagothenia hansoni increased 1.85 times, and for the interval between between $0^{\circ} \mathrm{C}$ and $10^{\circ} \mathrm{C}, 1.94$ times. Or the fin pectoral epaxial muscle sarcsomes, there was na increasing of 1.3 times of the respiration rate between $0^{\circ} \mathrm{C}$ and $10^{\circ} \mathrm{C}$. Respiration rates of isolated mitochondria from encephalon and fin pectoral epaxial muscle were also assayed with Trematomus bernacchii, at $0^{\circ} \mathrm{C}$, Lepidonotothen nudifrons, at $0^{\circ} \mathrm{C}$ to $10^{\circ} \mathrm{C}$ and with Trematomus newnesi, at $0^{\circ} \mathrm{C}, 5^{\circ} \mathrm{C}$ and $10^{\circ} \mathrm{C}$. The mitochondria respiratory activity was expressed in $\mathrm{m}(\mathrm{Mol} \mathrm{O} 2$. $\mathrm{L}-1$. $\mathrm{s}-1 / \mathrm{mg}$ of protein and respiratory control was measured between state 3 and 2 of respiration.

Key Words: respiratory, mitochondria, antartic fish. Apoio: CNPq/PROANTAR/SECIRM/PUCPR. 